\title{
ZOONOTIC ONCHOCERCIASIS CAUSED BY A PARASITE FROM WILD BOAR IN OITA, Japan
}

\author{
A COMPREHENSIVE ANALYSIS OF MORPHOLOGICAL CHARACTERISTICS OF THE WORMS FOR ITS DIAGNOSIS
}

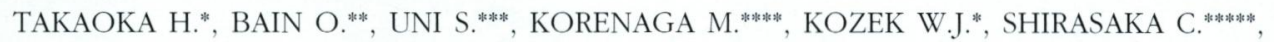 \\ AOKI C.*, OTSUKA Y.*, FUKUDA M.*, ESHITA Y.* \& DAA T.*******
}

\section{Summary:}

Histological examination of a nodule removed from the back of the hand of a 58-year-old woman from Oita, Kyushu, Japan showed an Onchocerca female sectioned through the posterior region of the worm (ovaries identifiable) and young (thin cuticle). Six Onchocerca species are enzootic in that area: $O$. gutturosa and $O$. lienalis in cattle, $O$. suzukii in serows /Capricornis crispus), O. skriabini and an Onchocerca sp. in Cervus nippon nippon, and $O$. dewittei japonica in wild boar (Sus scrofa leucomystax). Diagnostic characters of female Onchocerca species, such as the cuticle and its ridges, change along the body length. Tables of the histologic morphology of the mid-and posterior body-regions of the local species are presented. In addition, it was observed that transverse ridges arose and thickened during the adult stage lexamination of fourth stage and juvenile females of $O$. volvulus). The specimen described in this report, with its prominent and widely spaced ridges, was identified as $\mathrm{O} . \mathrm{d}$. japonica. Four of the 10 zoonotic cases of onchocerciasis reported worldwide were from Oita, three of them being caused by 0 . d. japonica, the prevalence of which in local wild boar was 22 of $24(92 \%)$.

KEY WORDS : zoonosis, Japan, Onchocerca dewittei japonica, wild boar
Résumé : ONCHOCERCOSE ZOONOTIQUe À OITA, JAPON AVEC LA DESCRIPTION D'UN QUATRIEME CAS

Une femme de 58 ans vivant à Oita, Kyushu, Japon, a un nodule sur le dos de la main; I'histologie révèle la présence d'une onchocerque femelle, jeune (cuticule mince), sectionnée dans la région postérieure (ovaires identifiés). Six espèces sont présentes dans la région: $\bigcirc$. gutturosa et $\bigcirc$. lienalis chez le bétail, O. suzukii chez le serow Capricornis crispus, $\bigcirc$. skrjabini et Onchocerca sp. chez Cervus n. nippon et $\mathrm{O}$. dewittei japonica chez le sanglier, Sus scrofa leucomystax. Un tableau de leurs caractères discriminatifs histologiques est effectué, en distinguant les régions moyenne et postérieure du corps. Des stades 4 et des femelles juvéniles d'onchocerque sont aussi observés (O. volvulus); elles montrent que les côtes transversales se forment et s'épaississent durant le stade adulte. Le spécimen étudié, avec ses côtes transversales remarquablement saillantes et espacées, peut être identifié à $\mathrm{O}$. d. japonica. Quatre des 10 cas d'onchocercose zoonotique connus dans le monde proviennent d'Oita et trois d'entre eux sont dûs à O. d. japonica; $92 \%$ des 24 sangliers examinés dans la région sont parasités par cette onchocerque

MOTS CLÉS : zoonose, Japon, Onchocerca dewittei japonica, sanglier.
Z oonotic onchocerciasis is a rare infection in humans: a total of nine cases has been previously described worldwide in the last 40 years (Burr et al., 1998; Pampiglione et al., 2001; Takaoka et al., 2001); interestingly, three of them were reported from the same locality, Oita, Kyushu, Japan; one case was described by both Beaver et al. (1989) and Hashimoto et al. (1990), and the others by Takaoka et al. (1996, 2001). The new case reported here also occurred

"Department of Infectious Disease Control, Oita University, Hasamacho, Oita 879-5593, Japan.

* Parasitologie comparée et Modèles expérimentaux, associé à l'INSERM (U567), Muséum National d'Histoire Naturelle et École Pratique des Hautes Études, 75231 Paris, Cedex 05, France.

*w* Department of Medical Zoology, Osaka City University Medical School, Abeno-ku, Osaka 545-8585, Japan.

***** Department of Parasitology, Kochi University, Nankoku-shi, Kochi 783-8505, Japan.

******* Notsuharu Hospital, Notsuharu-cho, Oita 879-7101, Japan.

******** Department of Pathology, Oita University, Hasama-cho, Oita 879-5593, Japan.

Correspondence: Hiroyuki Takaoka, Tel.: +81-97-586-5700

- Fax: +81-975-86-5702.

E-mail: takaoka@med.oita-u.ac.jp in this region, in a patient who has not travelled outside Kyushu. These four cases suggest the existence of local conditions favorable for the transmission of animal Onchocerca species to humans.

Oita is a region with cultivated areas, cattle ranches, and wild-life sanctuaries (Mt. Sobo, 1,756 $\mathrm{m}$ high) that shelter the wild ungulates: serows (Capricornis crispus Temminck), sika deer (Cervus nippon nippon (Temminck)) and wild boar (Sus scrofa leucomystax Temminck). Studies done during the past fifteen years (Takaoka et al., 1989; Takaoka \& Bain, 1990; Yagi et al., 1994; Takaoka, 1994; Uni et al., 1997; Takaoka, 1999; Uni et al., 2001) have shown the diversity of Onchocerca species enzootic in Oita. In addition to two cosmopolitan parasites from cattle, O. gutturosa Neumann, 1910, and O. lienalis Stiles, 1892, four other species have been identified from wild ungulates in Oita, of which one has not yet been described (Uni et al., in preparation): O. suzukii Yagi, Bain \& Shoho, 1994, from serow, which may also be transfuge in cattle (Uni et al., 1997), O. skrjabini Rukhlyadev, 1964, a palearctic species from cervids (Bain \& Schulz-Key, 1974; Barùs 

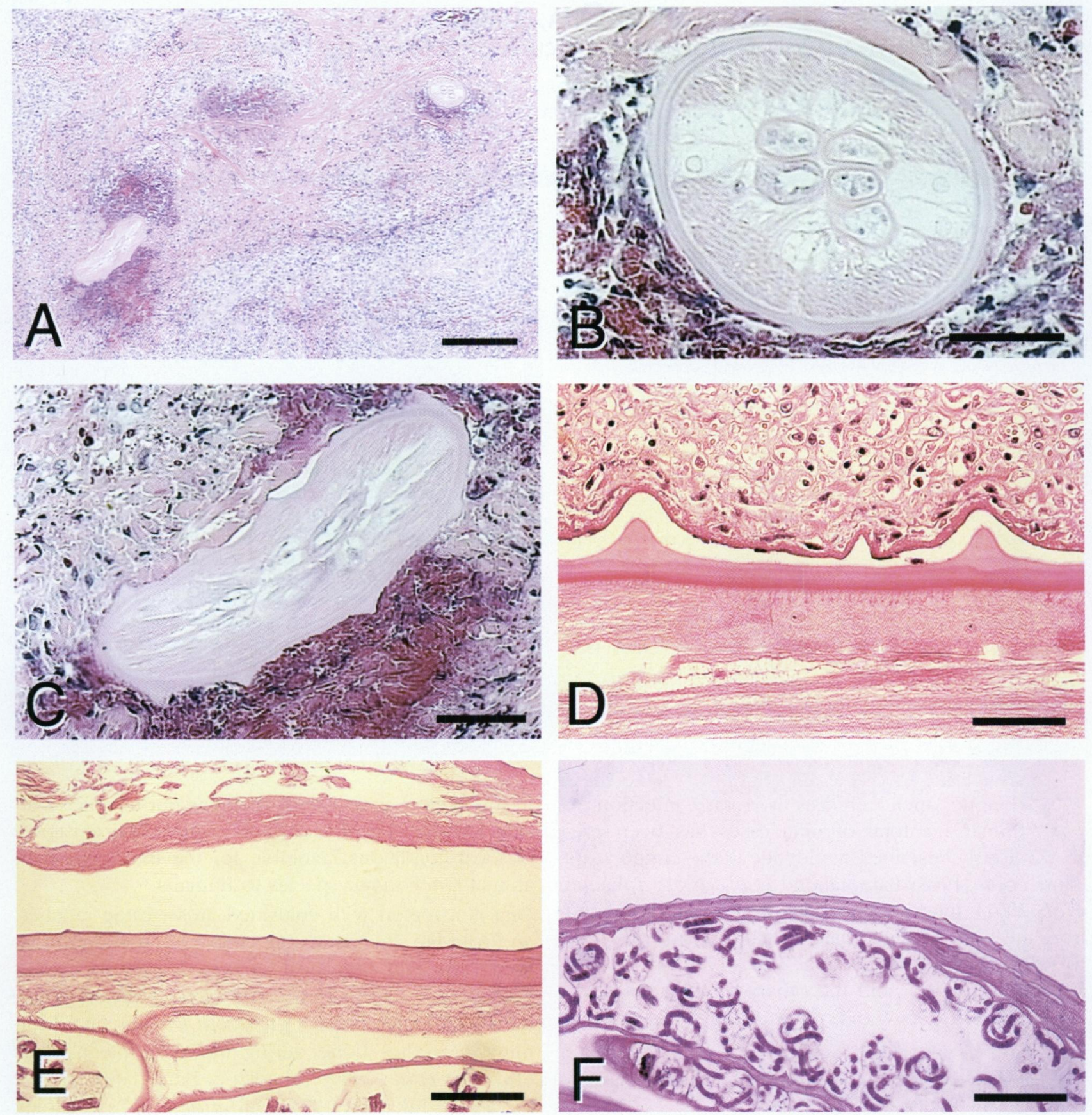

Fig. 1. - Onchocerca species in Oita, Japan, histologic sections. A to C, from the patient. A: Tumor showing the two worm sections and the surrounding tissue reaction. B: Transverse section of female worm showing the two-layered cuticle, tall somatic cells, marked lateral chords, four sections of ovaries (one or two reproductive ducts), and the small intestine. C: Longitudinal section of female worm showing marked transverse ridges on the external surface of the cuticle. D to F, Female body cuticle of three Onchocerca species from wild ungulates, longitudinal sections. D: O. dewittei japonica from wild boar. E: O. skrjabini from Cervus n. nippon. F: Onchocerca sp. from Cervus n. nippon.

Scales bars in $\mu \mathrm{m}: \mathrm{A}, 200 ; \mathrm{B}, 30 ; \mathrm{C}-\mathrm{F}, 50$. 
\& Koubek, 1993), and the closely related species, Onchocerca sp. Uni, Bain \& Takaoka, both from sika in Oita, and O. dewittei japonica Uni, Bain \& Takaoka, 2001, from wild boar.

Definitive identification was possible of the causative agent of one of the human cases as $O . d$. japonica (Takaoka et al., 2001) because the male filaria had the cuticular longitudinal crests characteristic of the male of this species (Uni et al., 2001). One specimen from the second human case (Takaoka et al., 1996), reported before the discovery of $O \cdot d$. japonica, was later shown to correspond to O.d. japonica (Takaoka et al., 2001). The filaria of the first case (Beaver et al., 1989; Hashimoto et al., 1990) had not been identified because only transverse sections were available for examination; however, the possibility was ruled out that it was the Onchocerca species from a serow discovered earlier (Suzuki et al., 1982), but not described at that time.

As part of the identification of the fourth case of zoonotic onchocerciasis in Oita reported here, we have summarized the characteristics of local Onchocerca species. These characteristics are visible in histologic sections and are based on descriptions of mature worms. We took into consideration that cuticular and hypodermal characteristics change along the length of the female. Moreover, the worm identified in this case report was apparently young, so we set out to collect data on the development of the cuticle and its ornamentation from the specimens of $O$. volvulus (Leuckart, 1893) material deposited in museum collections, for use for this diagnosis and identification of Onchocerca spp. in histologic sections.

\section{MATERIALS AND METHODS}

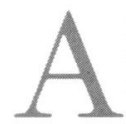

nodule was detected in early April 2003 in a 58-year-old woman living in Notsuharu, Oita Prefecture, in southwestern Japan. The subcutaneous swelling was on the back of the left hand; the lesion was inflamed and tender on April 10, 2003. The nodule, about $2.5 \mathrm{~cm}$ in diameter, was biopsied at Notsuharu Hospital on the same day, fixed in $10 \%$ formalin, sectioned, and stained with hematoxylin-eosin. Two histologic sections of the nodule available for study contained a nematode surrounded by granulomatous tissue infiltrated with many lymphocytes, histiocytes (= epithelioid cells), and eosinophils (Fig. 1A-C). The remains of the nodule (collection number MNHN $441 \mathrm{SE}$ ) were dissected in lactophenol for recovery of the remaining worm segments, but none was found. Laboratory examination and tests of the patient's blood and serum included a complete blood cell count, including a differential blood count, the activities of aspartate transaminase, alanine aminotransferase, and lactate dehydrogenase, and the C-reactive protein level. In addition, the patient's serum taken on April 16, 2003 was tested by ELISA (Korenaga et al., 1983) for O. gutturosa antigens. The sera of 13 Guatemalan people giving positive results for O. volvulus and those of 12 Japanese people giving negative results for the same worm were used as controls.

For comparative studies, we used histologic sections of $O . d$. japonica from wild boar, coll. number MNHN 442 and 443 SE and coll. number Osaka City University Medical School (OCUMS) 00133-1A (Fig. 1D); O. skrjabini from sika, coll. number OCUMS 02786-1 (Fig. 1E); Onchocerca sp. Uni, Bain \& Takaoka, 2003 from sika, coll. number OCUMS 20249-3 (Fig. 1F); whole specimens of $\mathrm{O}$. volvulus female fourth-stage larvae (no vulvar opening) recovered by H. J. Winkhardt in 1985 from an experimentally infected Syrian hamster, Mesocricetus auratus, coll. number MNHN, $310 \mathrm{ED}$; and two female young adults (vulva open), isolated from human nodules by H. Schulz-Key in 1982, coll. number MNHN, 444 SE.

The following histologic and morphologic characteristics of adult worms were taken from a key of Onchocerca species (Bain, 1981): (i) cuticle: thickness, number of layers, external ridges (spacing, height, and width at base), internal striae, longitudinal grooves, and lateral thickenings; (ii) symmetry of the body; (iii) hypodermal lateral chords: height and width at base; (iv) muscles: thickness, approximate number per quadrant; and (v) diameters of the intestine and the body. The morphologic characteristics of the midbody region were taken from published descriptions; for the posterior region, which has not been described in detail, we measured several published figures (Bain \& SchulzKey, 1974; Bain, 1975; Bain et al., 1978; Uni et al., 2001).

\section{RESULTS}

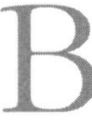
lood and chemistry tests were within reference limits except for eosinophilia $(6.5 \%)$ ). The patient's serum reacted with the $O$. gutturosa antigen. The optical density by ELISA for O. gutturosa antigen was as follows: 1.38 in the patient, 0.0275 (0.010 and 0.126 ; median with 25th and 75th percentiles) in Japanese subjects (negative controls) and 0.95 (0.51 and 1.90) in Guatemalan subjects (positive controls).

\section{DESCRIPTION OF WORM FROM THE PATIENT}

Only two histologic sections of the worm, one transverse (Fig. 1B) and the other oblique (Fig. 1C), were available for study. The description of the worm is as follows (Table I): dorsoventral symmetry of body, dia- 


\begin{tabular}{|c|c|c|c|c|c|c|}
\hline & \multicolumn{4}{|c|}{ Case reports from Oita, Japan } & \multirow{2}{*}{\multicolumn{2}{|c|}{$\begin{array}{c}\text { Worm sections } \\
\text { of } O \text {. d. japonica in tissues of natural host }\end{array}$}} \\
\hline & $\begin{array}{l}\text { Beaver } \\
\text { et al. } 1989\end{array}$ & $\begin{array}{l}\text { Takaoka } \\
\text { et al. } 1996\end{array}$ & Present study & $\begin{array}{l}\text { Takaoka } \\
\text { et al. } 2001\end{array}$ & & \\
\hline Worm sex & Female $^{\circ}$ & Female & Female & Male & Female, uterine level & Female, vaginal level ${ }^{\circ}$ \\
\hline Transverse ridges & Present & Present & Present & - & Present & Absent \\
\hline Longitudinalgrooves or crests & Absent & Absent & Absent & Present & Absent & Absent \\
\hline Dorsoventral symmetry & Yes & Yes & Yes & Yes & Yes & Yes \\
\hline Cuticle laterally thickened & No & No & No & - & No & No \\
\hline Internal transverse striae & - & Absent & Absent & - & Absent & Absent \\
\hline Cuticle thickness ${ }^{* * *}$ & $14-40^{\circ \circ}$ & $15-30$ & $4-7$ & $12-17$ & $8-32$ & 2.5 \\
\hline Outer $v s$. inner layer thickness ${ }^{* * *}$ & Thicker than 9-11 & Equal & Equal & - & Equal & - \\
\hline Ridge section & - & Sharp & Sharp & - & Sharp & - \\
\hline Ridge height/width** & _- & $11 / 22$ & $5-7 / 14$ & _- & $7-13 / 12-17$ & - \\
\hline Inter-ridge space*** & - & $67-105$ & $40-80$ & - & $110-150$ & - \\
\hline Lateral chord height/width*** & NR & $16-21 / 26-52$ & $22-24 / 16-20$ & $15 / 30$ & $10 / 45$ & $12 / 11$ \\
\hline Muscle height ${ }^{* *}$ & 30 & 30 & $18-30$ & 15 & 45 & 12 \\
\hline Muscle number per quadrant & 5 & $7-12$ & $5-7 ?$ & NR & $7-12$ & 6 \\
\hline Section diameter" & $190-238$ & $182-260$ & $80-100$ & $70-110$ & 150 & $70-80$ \\
\hline Intestine diameter*** & $5-20$ & $15-22$ & $12-22$ & 12 & 25 & 15 \\
\hline Worm identification & ? O.d. japonica & o.d. japonica & O.d.japonica & O.d. japonica & & \\
\hline Sex \& age of patient & $\mathrm{F}, 2$ years old & $\mathrm{F}, 57$ years old & $\mathrm{F}, 58$ years old & $\mathrm{F}, 52$ years old & & \\
\hline
\end{tabular}

*Unpublished data. ${ }^{*}$ Measurements in micrometers. NR, not reported. ${ }^{\circ}$ Transverse sections only. ${ }^{\circ}$ Including ridges and confirmed by Hashimoto et al., 1990 . F: woman.

Table I. - Morphologic characteristics of worm sections from the 4 human cases in Oita, compared with histologic sections of O. $d$. japonica from Sus scrofa leucomystax. 
meter 80-100 $\mu \mathrm{m}$. Cuticle: $4-7 \mu \mathrm{m}$ thick, composed of two layers equal in thickness; cuticle thicker sublaterally because the transverse section crossed through part of the ridges; external surface with prominent, sharp transverse ridges spaced $40-80 \mu \mathrm{m}$ apart, thickness of ridges twice that of cuticle; internal cuticular layer without transverse striae; longitudinal grooves absent. Lateral chords $22-24 \mu \mathrm{m}$ thick and up to $20 \mu \mathrm{m}$ wide. Thin hypodermis at base of muscles. Somatic muscles of the polymyarian-coelomyarian type, muscle cells about $18-30 \mu \mathrm{m}$ thick, apparently five per quadrant. Genital tract present only in the transverse section that contained four small sections identified to ovaries. Intestine, $12-22 \mu \mathrm{m}$ in diameter.

\section{HISTOLOGIC CHARACTERISTICS OF ONCHOCERCA SPECIES FROM OITA}

Key characteristics are shown in Fig. 2. Comparisons of the midregion and the posterior region are separate (Table II). The dorsoventral asymmetry of the body calls for comment. Such asymmetry is observed only in O. gutturosa; it has been described by Bain et al. (1978) and also by Eberhard in his Ph.D. dissertation (1976), but not in his subsequent article (1979). Also deserving comment are the longitudinal grooves of $O$. lienalis, described by Bain et al. (1978). Other characteristics such as ridges and internal striae of the cosmopolitan species have been described earlier by several authors (Beaver et al., 1974; Bain, 1975; Bain et al., 1978; Eberhard, 1976, 1979).

\section{Cuticle specialization of O. VOLVULUS}

The fourth-stage female has a thin cuticle with external striae like those normally seen in nematodes. Two young-adult females had a thin cuticle, $7-8 \mu \mathrm{m}$ at midbody, consisting of only one layer; the morphology of their cuticle depends on the degree of development of these worms. The smaller female, $22 \mathrm{~mm}$ long and $75 \mu \mathrm{m}$ wide, had an externally striated cuticle, without any ridge, identical to that of the male (Bain, 1975). The female that was $35.6 \mathrm{~mm}$ long and $70 \mu \mathrm{m}$ wide had delicate ridges, $4-6 \mu \mathrm{m}$ apart, in the midpart of the body; internal striae were absent (Fig. 2H). The larger female seemed to be beginning to develop its cuticular specialization. In the fully developed female, the cuticle is $10-30 \mu \mathrm{m}$ thick and is divided into two layers, the external layer with ridges $30-40 \mu \mathrm{m}$ apart, and the internal layer with two striae between adjoining pairs of ridges (Beaver et al., 1974; Bain, 1975). However, the anterior region of the female has the unspecialized morphology of all other Onchocerca species.

\section{DISCUSSION}

Whe specimen reported here was a female of an Onchocerca species characterized by the small diameter of the intestine, thin hypodermis (Beaver et al., 1989), and presence of several regularly spaced transverse ridges. The transverse section appears to be from the posterior region because it passed through the ovaries. The cuticle was thinner $(4-7 \mu \mathrm{m})$ than in other Onchocerca species, suggesting that the specimen was a young female. Observations of $O$. volvulus have shown cuticular thickening and acquisition of ridges during the adult stage. The young specimen of the human case reported here had salient ridges. Transverse ridges are lacking in O. suzukii and delicate in O. lienalis, O. skrjabini, and an Onchocerca sp. in Oita (Table II). Two other species, O. gutturosa and O. d. japonica, have salient ridges. In O. gutturosa, the cuticle is thickened in lateral areas, and the posterior region has ridges $10 \mu \mathrm{m}$ apart, instead of the $40-80 \mu \mathrm{m}$ for the specimen reported here. Moreover, in O. gutturosa, the body is dorsoventrally asymmetric, and the lateral chords are more towards the dorsal aspect, a difference accentuated in the posterior region (Bain et al., 1978; Eberhard, 1976). This difference was not found here, but the validity of this characteristic for identifying a young individual is uncertain, because the degree of asymmetry may change during maturation. The morphology of the nematode found in the case reported here fits with that of $O$. d.japonica, in which species cuticular ridges are present, and sharp in the posterior region, with a distance between them of 50 $80 \mu \mathrm{m}$ (Table II). Therefore, this filaria is identified as O. d. japonica. Beaver et al. (1989) noted the great variation in the cuticle thickness of their specimens and concluded that the variation arose because of the thick transverse ridges. The symmetry of the body of the female worm and the other characteristics fit those of O. d. japonica (Table I), so O. d. japonica was also the causative agent of this first case from Oita.

Four of the ten cases of zoonotic onchocerciasis reported worldwide at this date have occurred in Oita, Japan, and the causative agent incriminated in at least three of these human cases is O. d. japonica, a parasite of wild boar. In other countries, Onchocerca species from cattle or horses have been implicated in human infections. The presence of $O$. $d$. japonica in wild boar has recently been reported (Uni et al., 2001) and its prevalence is high in Oita: between August 22, 2001 and March 6, 2003, of the 24 wild boar examined for microfilariae in skin snips, $22(92 \%)$ had microfilariae of $O . d$.japonica. In contrast the prevalence of O. gutturosa, the other species with pronounced cuticular ridges, is $3.0 \%(4 / 134)$ in cattle (Takaoka, 1997). The vectors of $O$. gutturosa and $O$. lienalis from cattle 


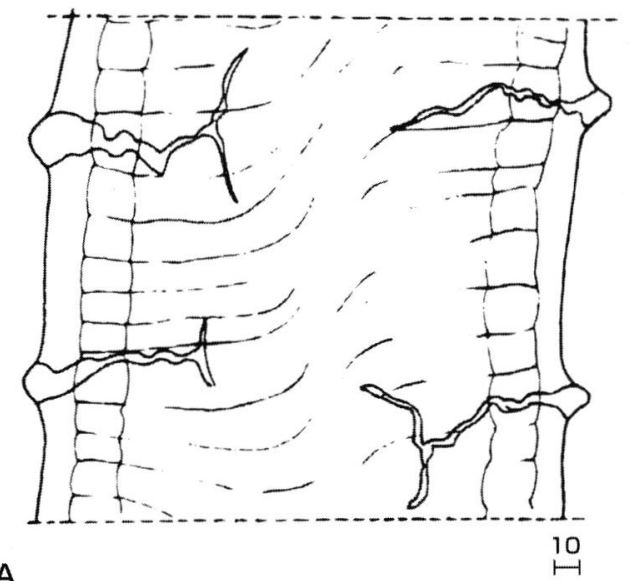

B
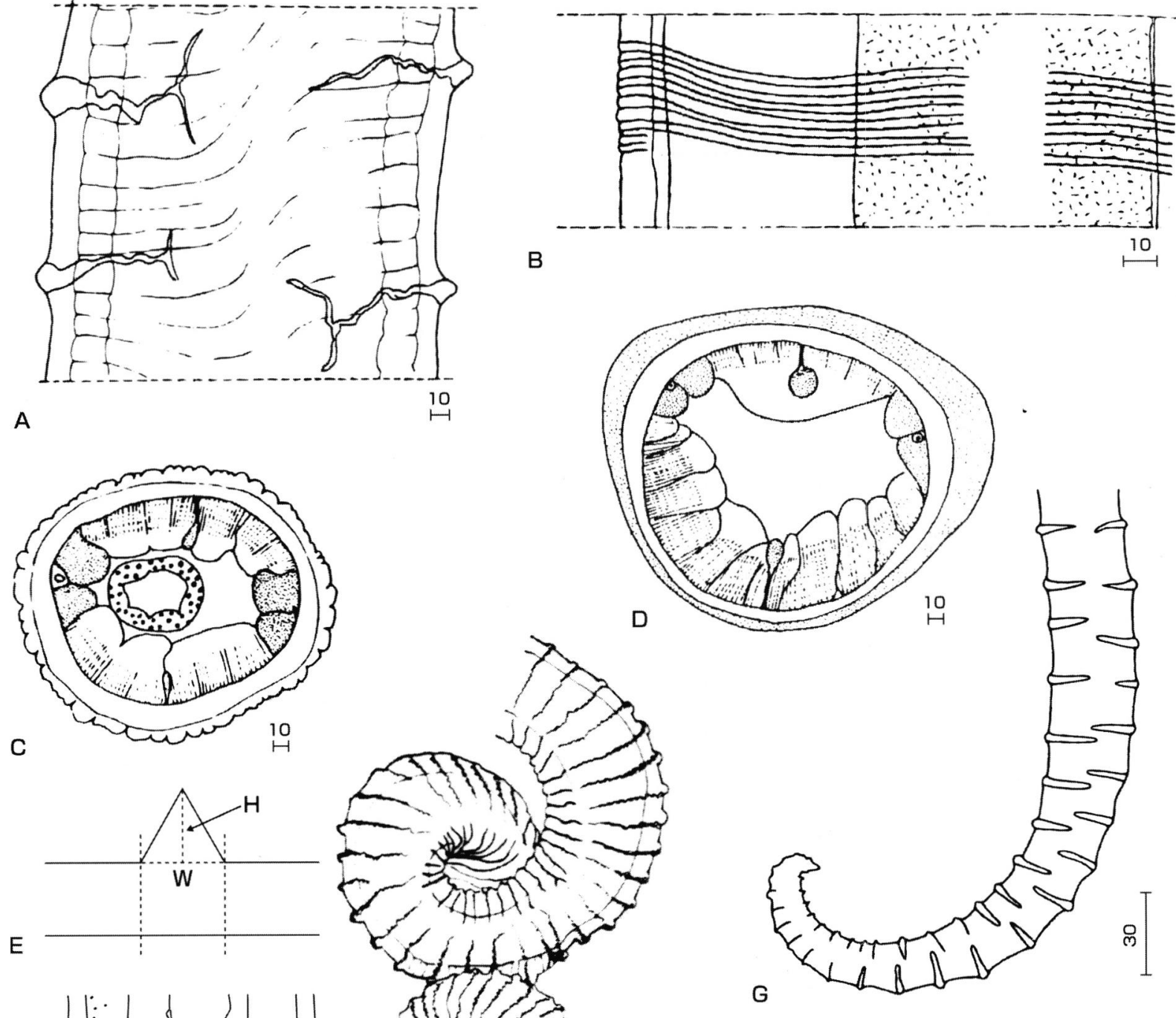

$E$

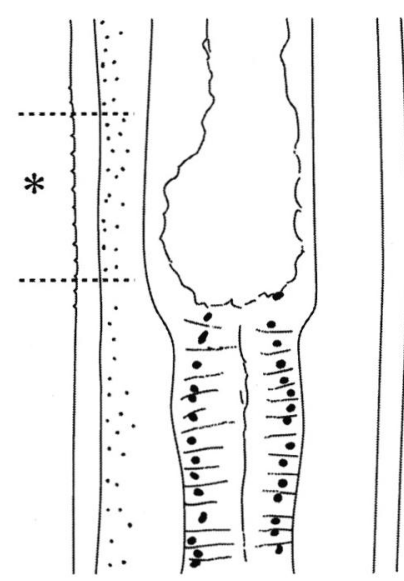

$\mathrm{H}$
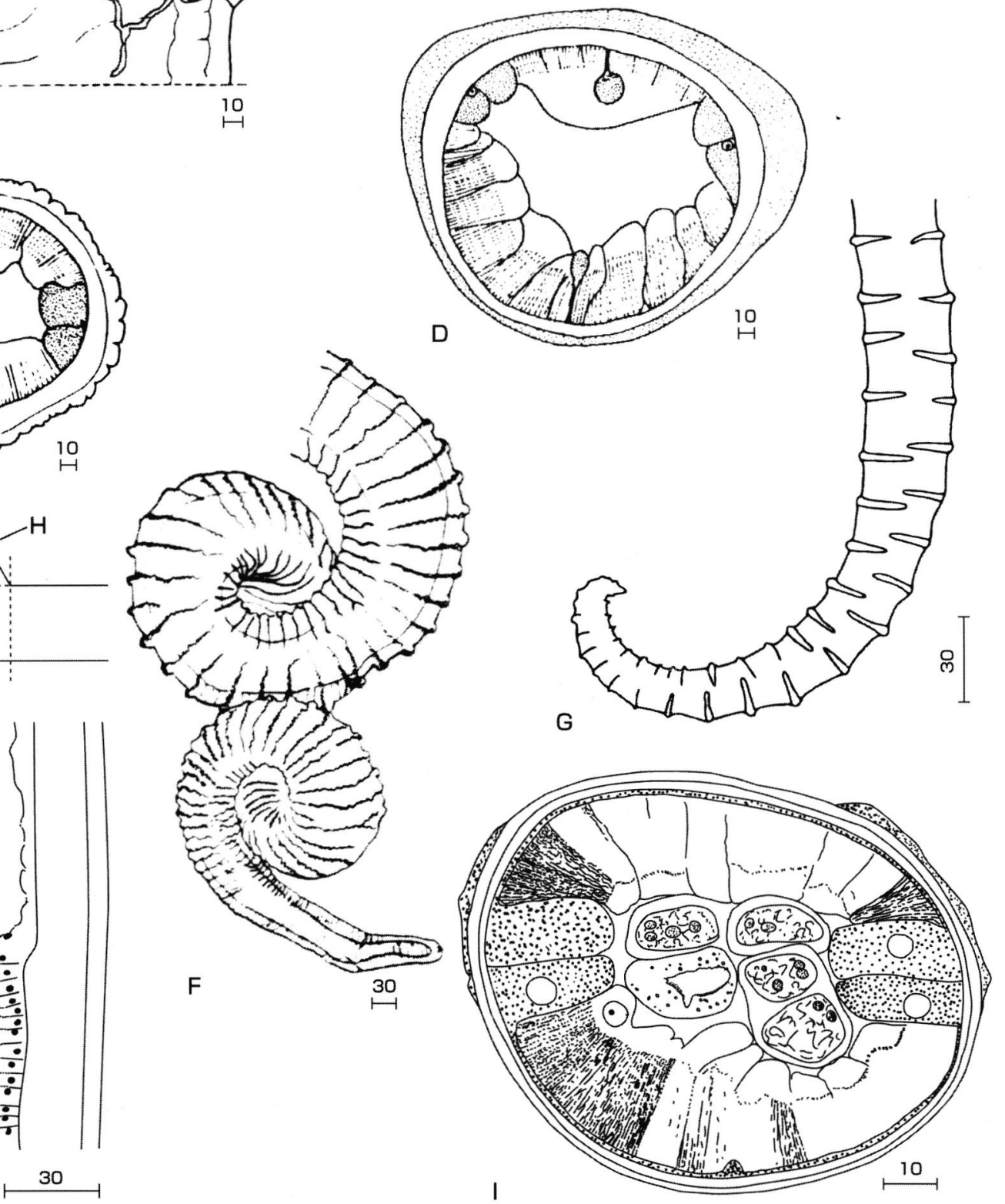

Fig. 2. - Cuticular female characteristics of Onchocerca species from cattle and wild ungulates in Oita, and from young O. volvulus. A: Transverse ridges and internal striae, O. gutturosa, midbody (from Bain, 1975). B: External striae, O. suzukii, midbody (from Yagi et al., 1994), C: Longitudinal grooves, O. lienalis, posterior region (from Bain et al., 1978). D: Dorsoventral asymmetry, lateral thickenings, O. gutturosa, posterior region (from Bain et al., 1978). E: Ridge, height (H) and width (W). F \& G: Habitus and ridges of posterior region of $O$. gutturosa (from Bain, 1975) and O.d. japonica (from Uni et al., 2001). H: Tiny cuticular ridges of O. volvulus, young-adult female $35.6 \mathrm{~mm}$ long and $70 \mu \mathrm{m}$ wide, at oesophageal-intestinal junction (* indicates the part with drawn ridges). I: Drawing of a transverse section of Onchocerca sp. of the present human case; ridges are sectioned at two places making the cuticle thicker (same as in Fig 1B). 


\begin{tabular}{|c|c|c|c|c|c|c|}
\hline & O. suzukii & O. lienalis & O. gutturosa & O. skrjabini & O. dewittei japonica & Onchocerca sp. \\
\hline Body transverse ridges & Absent & Present & Present & Present & Present & Present \\
\hline Longitudinal grooves & One lateral & All over the cuticle & Absent & Absent & Absent & Absent \\
\hline Dorsoventral symmetry & Yes & Yes & Dorsal reduction & Yes & Yes & Yes \\
\hline Cuticle laterally thickened & Slightly & No & Yes & Yes & No & No \\
\hline Internal transverse striae & Absent & 2 or undulations & $4-8$ & $3-4$ & Absent & 2 \\
\hline Cuticle thickness med./lat." & $20-30 / 20-30$ & $12-17 / 12-17$ & $25^{* * * *}[29]-35 / 50$ & $35 / 50$ & $20-30 / 20-30$ & $30 / 30$ \\
\hline Outer $v$ s. inner layer thickness & $4: 1$ & $1: 4$ & $1: 1$ & $1: 1$ to $1: 4$ & $1: 1$ & $1: 1$ \\
\hline Ridge shape & - & Very sinuous & Straight to sinuous & Slightly sinuous & Straight & Slightly sinuous \\
\hline Ridge section & - & Flattened & Sharp & Delicate & Sharp & Delicate \\
\hline Ridge height/width* & - & {$[3 / 22]$} & $12 / 5-10$ & $6 / 12$ & $18-25 / 25-50$ & $3 / 8$ \\
\hline Inter-ridge space* & - & $25-45$ & $70-80$ & $48-55$ & $140^{*}-250$ & $25-40$ \\
\hline Lateral chord height/width* & $37 / 155$ & $12-20 / 55-65$ & $20 / 100$ & $15 / 50$ & $20 / 60$ & $10 / 38$ \\
\hline Muscle height* & 52 & 25 & 40 & $15-20$ & $50-60$ & 23 \\
\hline Muscle number per quadrant & $5-7$ & $5-7$ & $4-6$ & $5-7$ & $6-7$ & - \\
\hline Intestine ${ }^{*}$ & $20-48$ & $13-30$ & $20-37$ & 38 & 17 & 15 \\
\hline Diameter at midbody* & $228-430$ & {$[150] 180-220$} & $140-225$ & $170-330[340]$ & $190-260$ & $60-120$ \\
\hline Diameter at posterior part", & 170 & $160-190$ & $75-90$ & 150 & 150 & 130 \\
\hline Diameter at anus* & 150 & 85 & $70-95$ & 110 & $70-120$ & 60 \\
\hline Cuticle thickness med./lat.* & $30-50 / 30-50$ & $20 / 20$ & $14 / 33$ & $16 / 16$ & $20-25 / 20-25$ & - \\
\hline Ridge height/width* & - & External striae & $10 / 10$ & External striae & $10-20 / 22-30$ & External striae \\
\hline Inter-ridge space* & - & - & 10 & - & $50-80$ & - \\
\hline Posterior part habitus & Straight & Tortuous & Spirally coiled & Straight & Straight & Spirally coiled \\
\hline Host(s) in Oita & $\begin{array}{c}\text { Capricornis crispus } \\
\text { Cattle }\end{array}$ & Cattle & Cattle & Cervus n. nippon & Sus scrofa leucomystax & Cervus n. nippon \\
\hline \multirow{2}{*}{ References } & Yagi et al., 1994 & Bain et al., 1978 & Bain, 1975 & Bain \& Schulz-Key, 1974 & Uni et al., 2001 & Ongoing study \\
\hline & Uni et al., 1998 & Eberhard, 1979 & Bain et al., 1978 & Yagi et al,. 1994 & Uni (unpublished) & Uni (unpublished) \\
\hline
\end{tabular}

* Measurements in micrometers. ** Young female. ${ }^{* * *}$ About $250 \mu \mathrm{m}$ anterior to anus. Med., median; lat., lateral. I I From Eberhard, 1979 , or Yagi et al., 1994 according to the species.

Table II. - Onchocerca species found in Oita: characteristics useful for diagnosis from histologic sections of human nodules. 
in Oita have been identified as being black flies (Takaoka et al., 1989; Takaoka \& Bain, 1990; Takaoka, 1994, 1999). The yet unidentified vectors of $O . d$.japonica from wild boar must be anthropozoophilic.

\section{ACKNOWLEDGEMENTS}

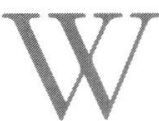
e thank Dr. H.J. Winkhardt and Prof. H. Schulz-Key for providing the O. volvulus specimens. W.J. Kozek would like to express his appreciation for the support obtained from the Museum National d'Histoire Naturelle, Paris and the Deanship of Biochemical Sciences Medical Sciences Campus, University of Puerto Rico.

\section{REFERENCES}

BaIN O. Redescription de cinq espèces d'Onchocerques. Annales de Parasitologie Humaine et Comparée, 1975, 50 , 763-788.

BaIN O. Le genre Onchocerca: hypothèses sur son évolution et clé dichotomique des espèces. Annales de Parasitologie Humaine et Comparée, 1981, 56, 503-526.

Bain O. \& Schulz-Key H. Les onchocerques du Cerf européen: redescription d'O. flexuosa (Wedl, 1856) et description d'O. tubingensis n. sp. et d'O. tarsicola n. sp. Tropenmedizin und Parasitologie, 1974, 25, 437-449.

Bain O., Petit G. \& Poulain B. Validité des deux espèces Onchocerca lienalis et O. gutturosa, chez les Bovins. Annales de Parasitologie Humaine et Comparée, 1978, 53, 421-430.

Barus V. \& KoubeK P. Evidence on the occurrence of Onchocerca skrjabini (Nematoda: Onchocercidae) in the Czech Republic. Helminthologia, 1993, 30, 105-108.

Beaver P.C., Horner G.S. \& Bilos J.Z. Zoonotic onchocerciasis in a resident of Illinois and observations on the identification of Onchocerca species. American Journal of Tropical Medicine and Hygiene, 1974, 23, 595-607.

Beaver P.C., Yoshimura H., Takayase S., Hashimoto H. \& LITTLE M.D. Zoonotic Onchocerca in a Japanese child. American Journal of Tropical Medicine and Hygiene, 1989, 40, 298-300.

Burr W.E., Brown M.F. \& EBerhard M.L. Zoonotic Onchocerca (Nematoda: Filarioidea) in the cornea of a Colorado resident. Ophthalmology, 1998, 105, 1494-1497.

EBERHARD M.L. The morphology of Onchocerca species (Nematoda: Filarioidea) found in cattle in the United States. Ph. D. Dissertation, Tulane University, New Orleans, Louisiana, 1976, $62 \mathrm{pp}$.

Eberhard M.L. Studies on the Onchocerca (Nematoda: Filarioidea) found in cattle in the United States. I. Systematics of O. gutturosa and O. lienalis with a description of O. stilesi sp. n. Journal of Parasitology, 1979, 63, 379-388.

Hashimoto H., Murakami L., Fujiwara S., Takayasu S., Takaoka H., Uga S., AKaO N., Kondo K. \& Yoshimura H. A human case of zoonotic onchocerciasis in Japan. Journal of Dermatology, 1990, 17, 52-55.

Korenaga M., Tada I., Mimori T., Sakamoto M., Lujan T.A., Zea F.G.E., Castro J.C. \& Yarzabal L. Enzyme-linked immunosorbent assay (ELISA) in the detection of IgG antibodies in onchocerciasis using blood collected on filter paper. Japanese Journal of Parasitology, 1983, 32, 347-355.

Pampiglione S., Vakalis N., Lyssimachou A., Kouppari G. \& Orinel T.C. Subconjunctival zoonotic Onchocerca in an Albanian man. Annals of Tropical Medicine and Parasitology, 2001, 95, 827-832.

Suzuki Y., Sugimura M., Yagi K., Ohbayashi M. \& Shoho C. Onchocerciasis in wild Japanese serows, Capricornis crispus. Japanese Journal of Veterinary Sciences, 1982, 44, 823-825.

TAKAOKA H. Natural vectors of three bovine Onchocerca species (Nematoda: Onchocercidae) and seasonal transmission by three blackfly species (Diptera: Simuliidae) in central Kyushu, Japan. Journal of Medical Entomology, 1994, 31, 404-416.

TAKAOKA $\mathrm{H}$. Interest in vectors of bovine Onchocerca species in Japan. Bulletin of Oita Veterinary Medical Association, 1997, 8, 3-6 (in Japanese).

TAKAOKA H. Review on zoonotic Onchocerca species and their insect vectors in Japan. Medical Entomology and Zoology, 1999, 50, 1-8 (in Japanese with an English abstract).

TAKAOKA H. \& BaIN O. Infections of blackflies (Diptera: Simuliidae) with three types of zoonotic Onchocerca larvae in Oita, Japan. Japanese Journal of Tropical Medicine and Hygiene, 1990, 18, 1-10.

Takaoka H., Baba M. \& Bain O. Natural infections of Simulium bidentatum (Diptera: Simuliidae) with larvae of Onchocerca spp., in relation to a human zoonotic onchocerciasis in Oita, Japan. Japanese Journal of Tropical Medicine and Hygiene, 1989, 17, 279-284.

Takaoka H., Bain O., Tajimi S., Nakayama I., Kashima K., Aoki C., Korenaga M. \& Otsuka Y. Second case of zoonotic Onchocerca infection in a resident of Oita, Japan. Parasite, 1996, 3, 179-182.

Takaoka H., Bain O., Uni S., Korenaga M., Tada K., Ichikawa H., Otsuka Y. \& Eshita Y. Human infection with Onchocerca dewittei japonica, a parasite from wild boar in Oita, Japan. Parasite, 2001, 8, 261-263.

Uni S., Suzuki Y., Chiba H., Katsumi A., Takaoka H. \& Bain O. An Onchocerca species from cattle on Kyushu Island is O. suzukii, a transfuge parasite from the Japanese endemic bovid, Capricornis crispus. Japanese Journal of Tropical Medicine and Hygiene, 1997, 26, 157-160

Uni S., Bain O., Takaoka H., Miyashita M. \& Suzuki Y. Onchocerca dewittei japonica n. subsp., a common parasite from wild boar in Kyushu Island, Japan. Parasite, 2001, $8,215-222$.

Yagi K, Bain O. \& Shoho C. Onchocerca suzukii n. sp. and O. skrjabini $(=O$. tarsicola $)$ from a relict bovid, Capricornis crispus, in Japan. Parasite, 1994, 1, 349-356.

Reçu le 3 novembre 2003 Accepté le 28 avril 2004. 